\title{
Pengaruh Intellectual Capital dan Struktur Modal Terhadap Return Saham \\ Dengan Kinerja Keuangan Sebagai Variabel Intervening (Studi pada Perusahaan Yang Terdaftar pada JII (Jakarta Islamic Index) Periode 2012-2016) Yefi Marlinda \\ Jurusan Akuntansi Program Studi Akuntansi \\ Universitas Islam Negeri Maulana Malik Ibrahim Malang \\ Email : yefimarlinda@gmail.com
}

\begin{abstract}
Intellectual capital is the company's wealth that is the power behind the company's value creation that includes knowledge, experience, skills, reputation, and also technological capabilities. Capital structure relates to sources of funds, both internal and external. The main purpose of this research is to investigate the relationship between intellectual capital and capital structure on stock return with financial performance as intervening variable. This type of research is quantitative research. The sample of this study is the annual financial statements of companies registered on JII (Jakarta Islamic Index) on period 2012-2016). The sample's were chosen by using purposive sampling method and 11 companies were able to fulfill the sample's criteria. The research data were analyzed by using path analysis method. The result of this research reported that there is indirect influence between intellectual capital and capital structure to stock return through financial performance measured by return on equity. Intellectual capital insignificance to indirect effect on stock return through financial performance measured through earning per share but there is indirect influence between capital structure on stock return through financial performance measured through earning per share. The study also found that intellectual capital insignificance on stock return. But the finding of direct influence between capital structure on stock return. From these findings it can be concluded that intellectual capital and capital structure indirect significance on stock return through financial performance measured through return on equity.
\end{abstract}

Keywords: Intellectual Capital, Debt to Equity Ratio, Return on Equity, Earning Per Share, Stock Return. 


\section{PENDAHULUAN}

Intellectual capital telah menjadi aset yang sangat bernilai. Hal ini menimbulkan tantangan bagi para akuntan untuk mengidentifikasi, mengukur dan mengungkapkannya dalam laporan keuangan (Sawarjuwono, 2003). Lalu dalam riset yang dilakukan oleh Purnomoshidi (2006) dalam Afifah (2014) menemukan bahwa rata-rata jumlah atribut IC yang diungkapkan dalam laporan tahunan perusahaan publik di Indonesia sebesar 56\%. Presetase ini menggambarkan bahwa perusahaan publik telah memiliki kesadaran terhadap arti penting IC bagi peningkatan keunggulan kompetitif, meskipun cara pengungkapan IC belum sistematis sesuai dengan kerangka kerja yang ada serta praktik pengungkapan IC diantara perusahaan masih bervariasi.

Kinerja suatu entitas bisnis maupun manajemen bisnis dewasa ini dapat diukur melalui struktur modal pada perusahaan tersebut. Bermula dari teori Modgilani-Miller (1958) dalam Takarini (2014) capital structure irrelevance proposition, yang mengasumsikan bahwa tidak terdapatnya bankruptcy cost, agency cost asymmetric information dan berada pada pasar yang efisien sehingga nilai suatu perusahaan tidak dipengaruhi oleh bagaimana perusahaan tersebut didanai (hutang dan ekuitas) dan bagaimana kebijakan devidennya. Menurut Stewart C. Myres (1984) dalam Takarini (2014) teori M\&M ini mempengaruhi munculnya pengembangan struktur modal seperti trade off theory dan pecking order theory. Dilihat dari sudut pandang kreditor, modal juga merupakan jumlah pinjaman yang tertanam di perusahaan. semakin baik kinerja perusahaan di mata kreditor, maka semakin tinggi tingkat kepercayaan kreditor untuk meminjamkan dananya kepada pihak bank dengan tingkat kepercayaan yang tinggi pada bank tersebut. Selain dari sudut pandang kreditor, struktur modal pada perusahaan yang sudah go public juga dapat dilihat dari sudut pandang pemegang sahamnya. Para pemegang saham tentunya akan menanamkan investasinya pada perusahaan yang memiliki kinerja yang baik.

Penelitian ini mengukur kinerja keuangan dengan menggunakan Return on

Equity (ROE) dan Earning per Share (EPS). Return on Equity (ROE) ini 
menunjukkan tingkat pengembalian (return) yang dihasilkan manajemen atas modal yang ditanam oleh pemegang saham, setelah dipotong kewajiban kepada kreditor. Menurut Brigham dan Housten (2001), Return on Equity (ROE) adalah rasio laba bersih terhadap ekuitas saham biasa, mengukur tingkat pengembalian atas investasi pemegang saham. Return on Equity (ROE) secara jelas mengukur keuntuangan perusahaan bagi pemilik saham biasa. Dimana bunga dan dividen dimasukkan ke dalam analisa laba yang didapat oleh suatu perusahaan dimana disalurkan ke pemilik modal. Sehingga dengan semakin tinggi return atau penghasilan yang diperoleh akan semakin baik pula kedudukan pemilik perusahaan. Rasio ini memperlihatkan kemampuan untuk menghasilkan laba atas investasi berdasarkan nilai buku para pemegang saham, dan seringkali digunakan dalam membandingkan dua atau lebih perusahaan dalam sebuah industri yang sama. Return on Equity (ROE) yang tinggi mengindikasikan penerimaan perusahaan atas peluang investasi yang baik dan manajemen biaya yang baik. Earning per Share (EPS) menggambarkan laba bersih setelah pajak pada satu tahun buku yang dihasilkan untuk setiap lembar saham.

Perusahaan yang digunakan dalam penelitian ini adalah perusahaanperusahaan yang terdaftar dalam indeks JII (Jakarta Islamic Index) tahun 20122016. Peneliti memilih JII (Jakarta Islamic Index) karena JII (Jakarta Islamic Index) terdiri dari 30 saham pilihan dari saham-saham yang sesuai dengan syariah Islam. JII berisi 30 saham yang disesuaikan setiap enam bulan (setiap bulan Januari dan Juli). JII diluncurkan pada tanggal 3 Juli 2000. JII diharapkan menjadi tolak ukur kinerja saham-saham yang berbasis syariah serta untuk lebih mengembangkan pasar modal syariah.

Berdasarkan fenomena di atas dengan hasil penelitian sebelumnya yang tidak konsisten, maka penulis akan melakukan penelitian yang berjudul "Pengaruh Intellectual Capital dan Struktur Modal Terhadap Return Saham Dengan Kinerja Keuangan Sebagai Variabel Intervening (Studi pada Perusahaan Yang Terdaftar pada JII (Jakarta Islamic Index) Periode 20122016)" 


\section{TINJAUAN PUSTAKA}

Resource-Based Theory (RBT) adalah suatu pemikiran yang berkembang dalam teori manajemen stretegik dan keunggulan kompetitif perusahaan yang meyakini bahwa perusahaan akan mencapai keunggulan apabila memiliki sumber daya unggul (Thaib, 2013). Berdasarkan resource-based view of the firm, sumberdaya perusahaan merupakan pemicu dibalik keunggulan versaing dan kinerja. Berbeda dengan pandangan sebelumnya yang lebih banyak memberikan penekanan dan peran strategis aset fisik berwujud, resource-based view of the firm, melihat bahwa kinerja unggul perusahaan hanya akan mungkin diacapai dengan mengakuisisi, memperoleh, menguasai, dan menggunakan aset-aset startegis yang vital bagi keunggulan bersaing dan kuat pengaruhnya bagi kinerja keuangan. Aset-aset strategis tersebut meliputi baik aset berwujud maupun aset tidak berwujud. Menurut Belkoui (2003), konsepsi resource-based view of the firm telah banyak diterima dalam disipilin ilmu dan literatur akuntansi, manajemen, ekonomi, dan manajemen strategik (Nasih, 2012).

Pada sisi lain, knowledge-based view of the firm memberikan penekanan pada peran strategis pengetahuan, Intellectual Capital serta kekayaan yang tidak berwujud (intangible asstes) sebagai sumber keunggulan bersaing dan untuk meraih kinerja superior. Kemampuan perusahaan untuk memobilisasi dan mengeksploitasi aset tidak berwujudnya jauh lebih menentukan daripada melakukan investasi dan mengelola aktiva fisik yang berwujud. Sumberdaya tidak berwujud (intangible resource) merupakan aktiva yang paling berharga bagi suatu peusahaan (Thaib, 2013).

Penelitian ini didasarkan pada stakeholder theory, dimana teori ini lebih menitikberatkan pada posisi para stakeholder yang dipandang lebih memiliki pengaruh. Kelompok inilah yang menjadi pertimbangan utama bagi suatu perusahaan untuk mengungkapkan atau tidak mengungkapkan suatu informasi dalam laporan keuangan. Kelompok-kelompok stakeholder disini bukan hanya mencakup pelaku usaha dan pemegang saham perusahaan, tetapi juga para pekerja/buruh/karyawan, pelanggan,pemasok, kreditor, pemerintah, masyarakat dan lingkungan dalam segala aspek operasional perusahaan. 
Satu kesepakatan umum dalam teori stakeholder dimana laba akuntansi hanyalah merupakan ukuran return bagi pemegang saham (stakeholder), sementara value added adalah ukuran yang lebih akurat yang diciptakan stakeholder dan kemudian disalurkan kepada stakeholder yang sama. Value added yang dipandang mempunyai ketepatan yang lebih tinggi dihubungkan dengan return yang dianggap sebagai ukuran bagi stakeholder (Daud \& Amri, 2008).

Secara umum, para peneliti mengidentifikasikan tiga konstruksi utama dari IC yaitu human capital (HC), structural capital (SC), dan relational capital (RC) (Bontis et al., 2000). Lebih lanjut, Bontis (2000) menyatakan secara sederhana HC mempresentasikan individual knowledge stock suatu organisasi yang dipresentasikan oleh karyawannya, SC meliputi seluruh non-human storehouse of knowledge dalam organisasi dan $\mathrm{CC}$ adalah pengetahuan yang melekat dalam marketing channels dan customer relationship dimana suatu organisasi mengambangkannya melalui jalannya bisnis. Sampai saat ini, defenisi modal intelektual seringkali dimaknai berbeda-beda. Sebagai sebuah konsep, modal intelektual merujuk kepada modal-modal tidak berwujud (intangible assets) yang mana terkait dengan pengetahuan manusia atau teknologi yang digunakan.

Menurut Sawarjuwono dan Kadir (2003) Intellectual Capitaldapat didefenisikan sebagai jumlah dari apa yang dihasilkan oleh tiga elemen utama organisasi (human capital, structural capital, customer capital) yang berkaitan dengan pengetahuan teknologi yang dapat memberi nilai lebih bagi perusahaan keunggulan bersaing organisasi. Lalu menurut Williams Intellectual Capital adalah proses penciptaan nilai melalui pengetahuan dan informasi yang diaplikasikan pada pekerjaan.

Struktur modal (capital structure) berkaitan dengan pembelanjaan jangka panjang suatu perusahaan yang diukur dengan perbandingan utang jangka panjang dengan modal sendiri. Struktur modal berkaitan dengan sumber dana, baik yang berasal dari dalam maupun dari luar perusahaan. sumber dana internal berasal dari dana yang terkumpul dari laba yang ditahan yang berasal dari kegiatan perusahaan. Sedangkan sumber dana eksternal berasal dari pemilik yang merupakan komponen modal sendiri dan dana yang berasal dari para kreditur 
yang merupakan modal pinjaman atau hutang. Modal dalam suatu bisnis merupakan salah satu sumber kekuatan untuk dapat melaksanakan aktivitasnya. Setiap perusahaan dalam melaksanakan kegiatannya selalu berupaya untuk menjaga keseimbangan finansialnya (Sudana, 2009).

Menurut Riyanto (2008), struktur modal adalah perimbangan atau perbandingan antara modal asing (jangka panjang) dengan modal sendiri. Struktur modal merupakan cermin dari kebijakan perusahaan dalam menentukan jenis securities yang ditentukan. Sedangkan menurut Sartono (2001), yang dimaksud dengan struktur modal merupakan perimbangan jumlah utang jangka pendek yang bersifat permanen, utang jangka panjang, saham preferen, dan saham biasa. Struktur keuangan adalah perimbangan antara utang dengan modal sendiri. Dengan kata lain struktur modal merupakan bagian dari struktur keuangan.

Return merupakan tingkat pengembalian yang diperoleh dari investasi. Return terbagi menjadi dua yaitu dapat berupa return realisasi yang sudah terjadi dan return ekspektasi yang belum terjadi tetapi diharapkan akan terjadi di masa yang akan datang. Return realisasi merupakan return yang telah terjadi yang dihitung berdasarkan data historis. Return realisasi digunakan sebagai salah satu faktor pengukur kinerja perusahaan. Return ini juga bekerja sebagai dasar penentuan return ekspektasi dan resiko masa datang. Return ekspektasi merupakan return yang diharapkan akan diperoleh untuk masa yang akan datang. Salah satu faktor yang membuat para investor menanamkan modalnya saat berinvestasi adalah return yang tinggi, dengan return yang tinggi maka investor berharap akan mendapatkan imbalan yang tinggi atas investasi yang dilakukan. Return yang diperoleh para investor tergantung oleh instrument yang digunakan (Eduardus, 2010 dalam Muna, 2014).

Return saham merupakan tingkat pengembalian yang diperoleh atas saham yang telah ditanamkan pada suatu perusahaan. Semakin tinggi tingkat pengembalian yang diperoleh oleh perusahaan maka mencerminkan bahwa semakin baik kinerja perusahaan tersebut.

Menurut Iswati, kinerja (performance) menjadi satu hal yang penting bagi manajemen, karena kinerja adalah hasil kerja yang dapat dicapai oleh seorang atau 
sekelompok orang dalam suatu organisasi sesuai dengan wewenang dan tanggung jawab masing-masing dalam rangka mencapai tujuan organisasi yang bersangkutan secara legal, tidak melanggar hukum dan sesuai dengan moral dan etika. Kinerja merupakan fungsi dari kemampuan organisasi untuk memperoleh dan menggunakan sumber daya dalam berbagai cara untuk mengembangkan keunggulan kompetitif (Wijaya, 2013).

Allah SWT memerintahkan umat-Nya untuk senantiasa menuntut ilmu dan menerapkan ilmu yang dimiliki dalam kebaikan serta dalam kehidupa sehari-hari. Ilmu yang kita miliki akan sangat menolong kita bahkan akan menjadi bekal ketika di akhirat kelak. Hal ini telah dikuatkan dalam salah satu hadits yang menyebutkan bahwa ada tigal hal yang akan mendorong kita agar terhindar dari siksa api neraka kelak, diantaranya adalah amal jariyah, ilmu bermanfaat, dan doa anak sholeh. Ayat dalam Al-Qur'an yang berkaitan dengan ilmu pengetahuan tersebut adalah QS. Al-'Ankabut (29) ayat 43:

$$
\text { و وتلك الأمثل نضربها للنّاس صلوما يعقلها إلّا العالمون (43) }
$$

"Dan perumpamaan-perumpamaan ini Kami buat untuk manusia,; dan tiada yang memahaminya kecuali orang-orang yang berilmu”.

Syahatah dan Fayyadh (2004) dalam Ma'ruf (2007), para ahli fikih kontemporer sepakat, bahwa haram hukumnya memperdagangkan saham di pasar modal dari perusaaan yang bergerak di bidang usaha yang haram. Misalnya perusahaan yang bergerak di bidang produksi minuman keras, bisnis babi dan apa saja yang terkait dengan babi, jasa keuangan konvensional seperti bank dan asuransi, dan insutri hiburan, seperti kasino, perjudian, prostitusi, media porno, dan sebagainya. Dalil yang mengharamkan jual beli saham perusahaan seperti ini adalah semua dalil yang mengharamkan segala aktivitas tersebut. Namun mereka berbeda pendapat jika saham yang diperdagangkan di pasar modal itu adalah dari perusahaan yang bergerak di bidang usaha halal, misalnya di bidang transportasi, telekomusikasi, produksi tekstil, dan sebagainya. Syahatah dan fayyadh berkata, "Menanam saham dalam perusahaan seperti ini adalah boleh secara syar'i.... Dalil yang menunjukkan kebolehannya adalah semua dalil yang menunjukkan bolehnya aktivitas tersebut". 
Pendapat lain menyatakan bahwa jual beli saham haram hukumnya meskipun perusahaan tersebut bergerak dalam bidang yang halal karena termasuk dalam spekulasi dan judi. Nabi melarang jual beli tanpa si penjual memberi kesempatan bagi si pembeli untuk meneliti barang yang dibelinya, misalnya hanya memgang tanpa melihat, atau langsung dilempar begitu saja. Boleh dikatakan, hampir semua pembeli di bursa saham membeli saham tanpa pernah pergi ke perusahaannya dan melihat asetnya apakah benar sesuai dengan laporan keuangan atau tidak. Hal ini sesuai dengan fiman Allah SWT dalam Q.S. An-Nisaa' ayat 29:

يأيها الذين عامنواً لا تأكلو ا أمولكم بينكم بالباطل إلّا أن تكون تجارة عن تراض منكمَّ و لا تقتلوا أنفسكمج إنّ الله كان بكم رحيما (29) (20)

"Hai orang-orang yang beriman, janganlah kamu saling memakan harta sesamamu dengan jalan yang batil, kecuali dengan jalan perniagaan yang berlaku dengan suka sama-suka diantara kamu, dan janganlah kamu memebunuh dirimu; sesungguhnya Allah adalah Maha Penyayang kepadamu".

\section{METODE PENELITIAN}

Jenis penelitian ini adalah penelitian kuantitatif dengan pendekatan deskriptif. Metode kuantitatif diartikan sebagai metode berlandaskan filsafat positivisme, digunakan untuk meneliti populasi atau sampel tertentu, teknik pengambilan sampel pada umumnya dilakukan secara random, pengumpulan data menggunakan instrumen penelitian, analisis data bersifat kuantitatif/statistik dengan tujuan tuk menguji hipotesis yang telah ditetapkan (Sugiyono, 2013). Menurut Siregar (2010) data kuantitatif yaitu data yang berbentuk angka atau data kualitatif yang diangkakaan dan menggunakan analisis statistik untuk mengolah datanya.

Populasi adalah sebuah kumpulan dari semua kemungkinan orang-orang, benda-benda, dan ukuran lein dari objek yang menjadi perhatian (Suharyadi \& Purwanto, 2012). Populasi yang digunakan dalam penelitian ini merupakan perusahaan-perusahaan yang terdatar di JII (Jakarta Islamic Index) dimana terdiri dari 22 perusahaan dari total sejumah 30 perusahaan. 


\section{HASIL DAN PEMBAHASAN}

Hasil analisis menunjukkan bahwa nilai standarized beta modal intelektual yaitu sebesar 0.706 , dengan nilai signifikansi $<0.05$ yaitu sebesar 0.002 , maka hal ini menunjukkan bahwa intellectual capital berpengaruh pada ROE. Hasil analisis juga menunjukkan bahwa nilai standarized beta DER yaitu sebesar -0.511, dengan nilai signifikansi $<0.05$ yaitu sebesar 0.020 , maka hal ini menunjukkan bahwa DER (struktur modal) berpengaruh pada ROE.

Hasil analisis menunjukkan bahwa nilai standarized beta modal intelektual yaitu sebesar 0.428 , dengan nilai signifikansi > 0.05 yaitu sebesar 0.060 , maka hal ini menunjukkan bahwa intellectual capital tidak berpengaruh pada EPS. Hasil analisis juga menunjukkan bahwa nilai standarized beta DER yaitu sebesar 0.540, dengan nilai signifikansi $<0.05$ yaitu sebesar 0.019 , maka hal ini menunjukkan bahwa DER (struktur modal) berpengaruh pada EPS.

Hasil analisis menunjukkan bahwa nilai standarized beta intellectual capital yaitu sebesar -0.271, dengan nilai signifikansi > 0.05 yaitu sebesar 0.220, maka hal ini menunjukkan bahwa intellectual capital tidak memiliki pengaruh langsung terhadap return saham.

Nilai standarized beta DER sebesar 0.583 dengan nilai signifikansi $<0.05$ yaitu sebesar 0.009 hal ini menunjukkan bahwa DER memiliki pengaruh langsung terhadap return saham.

Nilai standarized beta ROE sebesar 0.466 dengan nilai signifikansi $<0.05$ yaitu sebesar 0.001 hal ini menunjukkan bahwa intellectual capital dan DER memiliki pengaruh tidak langsung terhadap pada return saham melalui ROE.

Nilai standarized beta EPS sebesar -0.054 dengan nilai signifikansi > 0.05 yaitu sebesar 0.670 hal ini menunjukkan bahwa intellectual capital dan DER tidak memiliki pengaruh tidak langsung terhadap pada return saham melalui EPS.

Kesimpulan pola hubungan antar variabel dalam penelitian ini dengan menggunakan path analysis dijelaskan dalam tabel berikut

Berdasarkan uji hipotesis di atas, persamaan regresi dalam penelitian ini dapat ditulis sebagai berikut:

$\mathrm{ROE}=15,128+0,126 \mathrm{MVAIC}-3,102 \mathrm{DER}+5,894 \mathrm{e}$ 
$\mathrm{EPS}=245,900+2,900 \mathrm{MVAIC}-124,701 \mathrm{DER}+234,342 \mathrm{e}$

$\mathrm{RS}=-47,399-0,323 \mathrm{MVAIC}+23,709 \mathrm{DER}+3,125 \mathrm{ROE}-$ 0,009 $\mathrm{EPS}+36,286 \mathrm{e}$

Besarnya kontribusi pengaruh intellectual capital pada kinerja keuangan perusahaan yang diukur dengan ROE yaitu $(0.126)^{2}=0.0158$ atau sebesar $1.58 \%$ dan besarnya kontibusi pengaruh struktur modal pada kinerja keuangan perusahaan yang diukur dengan ROE yaitu $(-3,102)^{2}=9,6224$ atau setara dengan $962,24 \%$.

Besarnya kontribusi pengaruh intellectual capital pada kinerja keuangan perusahaan yang diukur dengan EPS yaitu $(2,900)^{2}=8,41$ atau sebesar $841 \%$ dan besarnya kontibusi pengaruh struktur modal pada kinerja keuangan perusahaan yang diukur dengan EPS yaitu $(-124,70)^{2}=15.550,09$ atau setara dengan $1.555,009 \%$.

Kontribusi pengaruh langsung intellectual capital pada return saham ada sebesar $(-0,323)^{2}=0,104$ atau sebesar $10,4 \%$ dan kontribusi pengaruh langsung stuktur modal pada return saham ada sebesar $(23,709)^{2}=562,11$ atau sebesar $56,21 \%$. Kontribusi pengaruh ROE pada return saham yaitu $(3,125)^{2}=9,765$ atau sebesar $976,5 \%$ dan kontribusi pengaruh EPS pada return saham yaitu $(-0,009)^{2}$ $=0,000081$ atau sebesar $0,0081 \%$.

\section{SIMPULAN}

Berdasarkan hasil penelitian, dapat disimpulkan bahwa:

1. Intellectual Capital dalam penelitian ini berpengaruh positif terhadap Return on Equity (ROE), artinya intellectual capital yang dapat dikelola dengan baik oleh perusahaan secara efektif dan efisien akan mencerminkan kinerja keuangan perusahaan yang baik, dengan demikian akan membuat para investor semakin banyak menanamkan dananya, sehingga akan memberikan tingkat pengembalian yang besar bagi pihak manajemen.

2. Struktur modal Debt to Equity Ratio (DER) berpengaruh signifikan terhadap Return on Equity (ROE). Artinya struktur modal yg dimiliki perusahaan baik, semakin baik struktur modal dalam sebuah perusahaan 
maka akan semakin meningkat pula Return on Equity (ROE)-nya. Return on Equity (ROE) dapat memberikan indikasi bagi manajemen mengenai pemilihan sumber pendanaan yang tepat untuk diambil dalam melihat keberhasilan perusahaan.

3. Intellectual capital tidak memiliki pengaruh signifikan terhadap Earning Per Share (EPS). Intellectual capital pada perusahaan initidak memiliki pengaruh terhadap tidak memiliki pengaruh signifikan terhadap Earning Per Share (EPS), yang berarti kurang baik dalam pengelolaan intellectual capital yang berdampak pada besarnya laba yang dihasilkan untuk setiap lembar saham.

4. Struktur modal berpengaruh terhadapEarning per Share Earning Per Share (EPS). Hal ini menyatakan bahwa adanya struktur modal yang baik pada perusahaan yang terdaftar pada JII (Jakarta Islamic Index).

5. Intellectual capital tidak berpengaruh terhadap return saham. Dalam penelitian ini, 4 dari 11 perusahaan mengalami kerugian selama beberapa tahun terakhir, sehingga kinerja keuangan perusahaan yang merupakan pencerminan pengelolaan intellectual capital dan juga sebagai sarana bagi investor dalam mengambil keputusan untuk menanamkan sahamnya, dinilai masih kurang baik dan tidak mampu memberikan sinyal yang baik kepada investor untuk menanamkan modalnya sehingga tidak berpengaruh terhadap return saham.

6. Struktur modal Debt to Equity Ratio (DER) berpengaruh terhadap return saham. Hal ini dapat diartikan bahwa Struktur modal Debt to Equity Ratio (DER) perusahaan JII (Jakarta Islamic Index) memiliki nilai Debt to Equity Ratio (DER) yang cukup tinggi, proporsi hutang lancar yang digunakan oleh perusahaan untuk melakukan kegiatan jual saham sehingga modal yang dimiliki perusahaan kembali.

7. Intellectual Capital berpengaruh secara tidak langsung terhadap return saham melalui kinerja keuangan yang diukur dengan Return on Equity (ROE). Hasil pengujian ini juga sesuai dengan resourse-based theory yang menjelaskan bahwa perusahaan dapat mempertahankan produktivitas 
dengan keunggulan kompetitif yang dimiliki perusahaan dengan cara mengimplementasikan strategi untuk menciptakan value added dalam hal ini Intellectual Capital yang tidak mudah ditiru oleh pesaing perusahaan.

8. Stuktur modal Debt to Equity Ratio (DER) berpengaruh secara tidak langsung terhadap return saham melalui kinerja keuangan yang diukur dengan Return on Equity (ROE). Investor yang melakukan investasi pada perusahaan akan mendapatkan laba atas saham yang dimilikinya, yang mendorong investor untuk mencari saham perusahaan yang akan mempengaruhi return saham perusahaan tersebut. Return yang diperoleh para pemegang saham tentu akan bertambah besar sehingga terjadi kenaikan return saham perusahaan.

9. Intellectual Capital tidak berpengaruh secara tidak langsung terhadap return saham melalui kinerja keuangan yang diukur dengan Earning Per Share (EPS). Informasi Earning Per Share (EPS) suatu perusahaan menunjukkan besarnya laba bersih per lembar saham yang siap dibagikan kepada pemegang saham, ketika perusahan tersebut mengalami kerugian tentu saja laba bersih per lembar sahamnya rendah.

10. Stuktur modal Debt to Equity Ratio (DER) berpengaruh secara tidak langsung terhadap return saham melalui kinerja keuangan yang diukur dengan Earning Per Share (EPS). Hasil penelitian ini memperlihatkan bahwa Stuktur Modalyang diungkapkan dalam laporan keuangan dapat meningkatkan nilai pasar dari perusahaan yang tercermin pada harga saham perusahaan. Saat laba bersih naik dan jumlah lembar saham biasa turun maka Earning Per Share (EPS) akan naik. Oleh karena itu semakin tinggi kemampuan perusahaan untuk mendistribusikan pendapatan kepada pemegang sahamnya maka semakin besar pula keberhasilan usaha yang dilakukannya. Hal tersebut juga akan mengakibatkan ketertarikan yang besar dari investor dan dapat menyebabkan naiknya harga saham 


\section{DAFTAR PUSTAKA}

Al-Qur'an al-Karim dan terjemahan

Afifah, Annisa Nur. (2014). Analisis Pengaruh Intellectual Capital Terhadap Nilai Perusahaan Yang Terdaftar di JII Periode 2010-2013. Skripsi. Fakultas Syariah dan Hukum Universitas Islam Negeri Syarif Hidayatullah, Jakarta

Bontis, N. (1998). "Intellectual Capital; an Exploratory Study that Develops Measures and Models Management Decision", Vol. 36 No. 2, pp 63-76. 1998

Bontis, N. (2001). "Assessing Knowledge Assets; a review of the Models Used to Measure Intellectual Capital", International Journal of technology Management. Vo. 3 No. 1. Pp. 41-60

Brigham dan Houston. (2001). Manajemen Keuangan II. Jakarta: Salemba Empat

Brigham, Eugene F., Houstan, Joel F. (2006). Dasar-dasar Manajemen Keuangan. Jakarta: Salemba Empat

Ma'ruf, Farid. (2007). Jual Beli Saham Menurut Islam. Jual Beli dalam Pandangan Islam. Diperoleh tanggal 10 September 2017 dari http://fandyrases.blogspot.com/2013/01/jual-beli-saham-menurutislam.html diakses pada Minggu, 10 September 2017 pkl. 10.10 WIB

Nasih, Moh. (2012). Intelektual Kapital dan Kinerja Perusahaan Perbankan di Indonesia. Staff Pengajar Ekonomi Universitas Airlangga.

Riyanto, Bambang. (2001). Dasar-dasar Pembelanjaan Perusahaan. Yogyakarta: BPFE UGM

Sartono, Agus. (2001). Manajemen Keuangan Teori dan Aplikasi. BPFE: Yogyakarta

Sawarjuwono, Tjiptohadi dan Agustine Prihatin Kadir. (2003). "Intellectual Capital: Perlakuan, Pengukuran, dan Pelaporan”. Jurnal Akuntansi Keuangan Vol.5, Surabaya

Siregar Sofian. (2001). Statistika Deskriptif untuk Penelitian. Jakarta: PT. Raja Grafindo Persada

Sugiyono. (2009). Metode Penelitian Kuantitatif Kualitatif dan R\&D. Bandung: Alfabeta

Sugiyono. (2013). Metode Penelitian Bisnis. Bandung: PT. Alfabeta 
Takarini, Agustin. (2014). "Pengaruh Intellectual Capital, Kualitas Penerapan Good Corporate Governance, dan Struktur Modal Terhadap Kinerja Keuangan Perbankan Syariah Periode 2010-2012”. Skripsi. Fakultas Syariah dan Hukum Universitas Islam Negeri Syarif Hidayatullah, Jakarta.

Thaib, Faczal. (2013) . "Value Added Intellectual Capital (VAHU, VACA, STVA), Pengaruhnya Terhadap Kinerja Keuangan Bank Pemerintah Periode 2007-2011”. Jurnal EMBA, Vol. 1, No.3

www.idx.co.id, diakses tanggal 1 Oktober 2017 